\title{
(息)
}

Citation:

Bradley, Q (2019) Combined Authorities and material participation: The capacity of Green Belt to engage political publics in England. Local Economy, 34 (2). pp. 181-195. ISSN 1470-9325 DOI: https://doi.org/10.1177/0269094219839038

Link to Leeds Beckett Repository record:

https://eprints.leedsbeckett.ac.uk/id/eprint/5897/

Document Version:

Article (Accepted Version)

The aim of the Leeds Beckett Repository is to provide open access to our research, as required by funder policies and permitted by publishers and copyright law.

The Leeds Beckett repository holds a wide range of publications, each of which has been checked for copyright and the relevant embargo period has been applied by the Research Services team.

We operate on a standard take-down policy. If you are the author or publisher of an output and you would like it removed from the repository, please contact us and we will investigate on a case-by-case basis.

Each thesis in the repository has been cleared where necessary by the author for third party copyright. If you would like a thesis to be removed from the repository or believe there is an issue with copyright, please contact us on openaccess@leedsbeckett.ac.uk and we will investigate on a case-by-case basis. 


\section{Combined Authorities and material participation: the capacity of Green Belt to engage political publics in England}

By Quintin Bradley

Leeds Beckett University

\section{Corresponding author:}

Dr. Quintin Bradley

Senior Lecturer in Planning \& Housing, Leeds Beckett University

The Northern Terrace, Leeds LS2 8AG, United Kingdom

Tel: $44(0) 1138129164$

\section{q.bradley@leedsbeckett.ac.uk}

Accepted for publication in Local Economy Vol 34, Issue 2, 2019: Special issue

Combined Authorities in England. Moving beyond devolution: Developing strategic local government for a more Sustainable Future?

\section{Abstract}

The aim of this paper is to consider the passions aroused by Green Belts in their urban containment function as a political accomplishment that has the capacity to orient publics around new spaces of governance. The paper addresses what it identifies as a problem of relevance in the new Combined Authorities in England where public identity and belonging may be more firmly rooted in other places and settings. It draws on the literature on material participation to locate the capacity to foster public belonging in objects, things and settings, and considers the environmental planning designation of Green Belt as an assemblage of the human and non-human which has the power to connect and contain. In a case study of plans for Green Belt reduction in the Greater Manchester Combined Authority the paper evidences the power of the non-human to mobilise public engagement and to foster territorial identity. The paper concludes by setting out an approach to public 
participation that foregrounds the importance of material interests and affective relations with objects and things in the formation of political communities.

$\underline{\text { Key words }}$

Combined Authorities, Green Belt, material participation, publics

$\underline{\text { Introduction }}$

A spatial reorganisation of governance demands a corresponding organisation of publics around new territorial settings. As imagined communities, the Combined Authorities emerging in English government require the recognition of subjects whose sense of belonging may be more firmly rooted in other places and settings (Anderson 1991). Established as new sub-regional institutions of governance in England post-2010, the Combined Authorities face a problem of relevance (Marres 2012). Headed by a directlyelected Mayor and with statutory powers devolved from central government, they are new forums of democracy with a requirement to engage public participation. In most cases, their political boundaries do not correspond with territorial identities drawn from distinct landscapes and environments. It is their ability to take decisions across borders, under a new level of co-ordination and leadership on issues of economic development, spatial planning, and transport - matters beyond the interests of any one individual locale - that provides their statutory function (House of Commons, 2017).

This paper is concerned with the capacity of spatial planning and its environmental designations to provide the networks of belonging that might inaugurate and engage publics with these new territorial projects of government. It investigates the 'powers of engagement' (Marres, 2012: 106) invested in Green Belt, an environmental designation internationally adopted by spatial planning regimes, and famously associated with the arousal of passionately loyal identification. The argument made here is that the awakening of such passion needs to be considered as a political accomplishment and the paper investigates the work done by Green Belts to engage publics in political debate and to orient them towards the settings of democratic governance. 
The paper seeks to contribute to an emerging literature on material participation that asks how non-human entities can be understood to organise and mobilise publics. It presents a case study of the performative agency of Green Belt in mobilising publics around the first of the English Combined Authorities to be established, the Greater Manchester Combined Authority in North West England, where a spatial planning framework published in late 2016 set out proposals to allocate Green Belt land for development to enable sub-regional economic growth. In research with the publics mobilised by the threat to Green Belt the paper charts the mediation of their attachments and allegiances that resulted in an emerging identification with the Combined Authority as a political entity and their engagement in competing visions of its future. The paper begins with a discussion of the relation of political publics to the new spaces of governance and introduces a topological approach to the problem of relevance in Combined Authorities in which the role of the nonhuman and of material participation is emphasised. In the following section, Green Belt is considered as a spatial planning practice that organises the attachments of the human for the non-human and that has the capacity to engage publics in issues and communities. $\mathrm{A}$ methodological framework for the case study is then set out, and the paper explores in primary research the capacity of Green Belt to inspire public engagement in place and regional identity. The paper concludes that the environmental designation of Green Belt can be understood as an instrument of 'collective becoming' that is constitutive of citizen engagement and can enact the new imagined communities of the English Combined Authorities (Metzger 2013a: 793).

\section{Material participation and the Combined Authorities}

The idea that publics exist ready to be mobilised by the institutions of government and swept up into the democratic process provides an enabling accompaniment to a spatial restructuring of governance. In this rationale the territorialisation and re-territorialisation of government bestows political identity on a public which already exists 'in a natural state waiting to be discovered' (Chilvers \& Kearnes, 2016: 4). The invitation to public participation is simply extended from one site of spatial governance to another, with the expectation that publics will follow. The appropriateness of the sites and processes of governance remains unquestioned, and the burden falls on the public to justify their presence or absence in 
response to the extension of an invitation. The theorist Noortje Marres (2012) has challenged this definition of participation with its assumption that sites of governance have innate political relevance. She argues that publics may be closely engaged in political issues but remain distant from the sites of issue formation. What Marres (2012: 140) calls 'relations of relevance' have to be established between the issues that mobilise public engagement and the sites of governance in which the democratic process is confined. Alongside other theorists in the field of Science and Technology Studies, Marres (2005a, 2005b) insists on the capacity of issues to call publics into being. She argues that issues, or 'matters of concern' (Latour, 2005a: 23), are constitutive of political publics. Not everyone engages in political activity to fulfil the obligations of citizenship to participate in democratic life. People get involved because they are adversely caught up in issues and they participate as democratic citizens through their attachments to these issues (Zakhour \& Metzger, 2018).

An essential stage in the emergence of a public around an identification with a Combined Authority and its sub-regional territory of governance is a demonstration of 'territorially framed common concerns', or issues that can only be resolved through cross-boundary democratic organisation (Metzger 2013: 1377). This entails the translation of individual and localised attachments into an assemblage of common cause, of grievances and issues that are shared across territory. It is, in part, a demonstration of relevance (Barry, 2001), in which political geographies acquire place identity by making visible the attachments and relationships that construct them (Farias 2010). In this perspective, places are conceived not as fixed points in a topographic geography but as the meeting points of multiple connections (Castells 2012). Local and global, and by inference place and sub-region, 'offer points of view on networks that are by nature neither local nor global but more or less long and more and less connected' (Latour, 1991: 122). Network space is topological, then; like Harry Beck's iconic map of the London Underground, it is a flattened landscape of lines and points in which some locations are drawn nearer together, while, with little regard for their proximity in geographic space, others are pushed further apart. Questions of scale arise only in the perceptions of actors as they define themselves in relation to each other, and to other lines and points, to provide a context for their own actions. Latour flattens the geographic concepts of scale and region through an analogy with infrastructures of technological networks. He argues that railway tracks, gas lines and sewer pipes are neither local nor 
global, nor do they jump to another scale; instead they connect and align places in 'a series of branchings that cross other places and require other branches in order to spread' and link other points to the network (Latour, 1991: 117). The only things that have any concrete existence are the conduits of the pipeline or the tracks of the railway and the distance to the next point.

Through this analogy it is possible to envisage a Combined Authority not as a scalar jump from one level of political decision-making to another, nor as a collection of places collated within a political boundary, but as a topological network in which places, publics and political actors are pulled into closer connectivity, distances are dissolved, and existing relationships re-routed (Mol \& Law, 1994). Networks generate spaces by enrolling actors and their locales. They create the connections through which 'Locals are localised. Places are placed' (Latour 2005a: 195). According to Callon's theory of translation, to establish itself as an effective institution of governance, a Combined Authority has to enrol places and publics, align their interests with its own aims, and establish itself as the 'obligatory passage point' through which these actors pass in order to pursue their goals (Callon, 1986: 196). In this process, the Combined Authority is firstly presented as offering something that others need (local authorities, their political actors, stakeholders and publics) so that the interests of the enrolled are translated into those of the Combined Authority. The Combined Authority is established then as the most convenient route through which its enrolled actors can follow their interests and in the final stage, the Combined Authority becomes indispensable to its actors and publics and is established as the central point of all actions (Latour, 1988).

Callon's theory of translation functions as an analytical device for understanding how publics and places come to be enrolled in a project of identity construction without its associated connotations of individual autonomy and causation (Murdoch, 2006). Places as Massey (2005) argued, mark the location of specific intersections between humans and nonhuman entities embedded in wider constellations. The identity of any place, or any subregion, is demonstrated through an assemblage of objects as well as people, each speaking of connections to other places. Identification with place is an articulation of attachment to a particular entanglement of objects and people. Rather than think of purposeful human actors constructing projects of identity, Latour (1999: 26) points instead to the agentic 
capacity of objects and things, as well as people, as 'a chain of mediators, each not being the exact cause of the next, but instead, each enabling the next to become in turn, the originator of action'. Place and sub-regional identity, it can be argued, evidence the capacity of particular objects, in specific settings, to enrol actors and to organise their engagement. The relational publics that emerge from this topological reading of place are heterogeneous assemblies in which people and things are entwined. Objects as well as people emerge as democratic actors; they have the power to mobilise passionate debate and to assemble collective identities.

'There might be no continuity, no coherence in our opinions, but there is a hidden continuity and a hidden coherence in what we are attached to. ...Each object gathers around itself a different assembly of relevant parties. Each object triggers new occasions to passionately differ and dispute. Each object may also offer new ways of achieving closure without having to agree on much else" (Latour 2005b: 15).

In this excerpt from Making Things Public, Latour emphasises the power of the non-human to assemble publics around issues. Things, objects and settings have the capacity to affect, and the 'agentic contributions of non-human forces' (Bennett 2010: xvi) appear able, in specific settings, to organise or inspire political collectives. Objects can be recruited as actors in a demonstration of common concern and become the means through which publics can express their engagement in political issues.

This form of material participation has emerged in recent years as a means of orchestrating public engagement in environmental concerns. Everyday material objects such as low energy light bulbs, smart meters, and plastic bags, among other things, have been allocated key roles in mediating public action on the environment and invested with the capacity to organise and enable collection action. In this 'object-centred participation', citizen engagement emerges from things (Marres, 2012: 9), or more precisely, things provide the settings and sites in which participation takes place. Participation takes place through these objects and it is the non-human, the object, that participates, as much as the human. The study of material participation brings attention to the settings and things that enact issues and that assemble publics around them. It posits an inclusive definition of a democratic public in which human and non-human are entangled inextricably, and points to the interdependency of people, things and their environment. 
The political community conjured by the spatial reorganisation of governance is more than human and, as environmental theorists would argue, is threaded by networks of obligation that extend in time as well as space (Jasanoff, 2010; Stengers, 2005). The formation of such a community depends on human ability to enter into affective relations with things, and the capacity of things to activate publics. The next section explores the capacity of the environmental planning designation of Green Belt to organise and enable public participation in the urban governance of the Combined Authorities.

\section{Green Belt as a network of collective becoming}

The capacity of Green Belt to engage public passions is universally acknowledged. As an environmental designation, Green Belt was introduced in the UK from versions in Australia and USA in the early years of the $20^{\text {th }}$ Century, and spread internationally, in response to public concern over unregulated urban expansion. As a resolution of this issue, it demonstrated the ability of spatial planning practices to enrol landowners, conservationists and the outdoors movement around shared objectives (Ravenscroft 1998), and it organised the attachments between human and the non-human to stage a production of 'nature' in opposition to the urban as a barrier to its growth (Hinchcliffe et al 2005). The primary objective of Green Belt in UK since 1955 has been to contain urban sprawl (MHCLG 2018; MHLG 1955). It achieved this aim by reifying 'nature' as a category outside of politics and outside of the institutional reach of planning. Green Belt preserved a 'nature' that was the pastoral antithesis of the urban (Latour, 2004). It marked the constitutive outside of the economic realm (Porter, 2010), becoming a source of distributed agency for claims on nature as an escape from the urban, and for the urban fringe as a setting for accessible biodiversity. Green Belt displaced human attachments for the non-human onto an environmental setting where nature could be encountered, not as a distant concept, but as the territory underfoot, ready at hand on the edge of the urban (Latour et al, 2018: 355). Now making up around 13 per cent of land in England, Green Belts are valued popularly as 'places to enjoy quiet recreation' (CPRE \& Natural England, 2010: 7). The first Green Belt plans for London in the early 1900s expressed the need to preserve public amenity and provide space for recreation (Freestone, 2002), and their role as 'nature on the doorstep' continues to be dominant in the popular imagination. 
An essential characteristic of Green Belt, in addition to its openness and permanence as UK planning policy states, is its capacity to enrol and connect. It possesses the belt-like, girdlelike quality of a network. Linking as it does a collective of people, plants, animals, insects, and minerals, Green Belt extends a chain of mediation between the attachment of humans to animals, evidenced in taking the dog for a walk along a footpath, to the fields and woods threaded by the public right of way, to the human sensation of wellbeing achieved by hearing bird song, seeing wildlife and smelling damp earth (Duff 2011), and on to an attachment to 'nature', to conservation, to the 'environment' as issues of concern (Hinchcliffe et al 2005). The issues, as much as the individual attachments to a dog and a walk along a footpath, act as mediators enrolling participants behind the idea of Green Belt and mobilising their engagement in debates over the politics of economic development, environmental protection and urban governance.

The production of 'nature' as a barrier to urban growth suggested an outward facing public finding engagement beyond the city limits. It masked the extent to which the circle of Green Belt acted as a reversal, investing the city itself with powers of engagement emanating from the limits on its trans-local growth, and the probing demands on its boundaries (McFarlane, 2009). In establishing a cordon between 'society' and 'nature', Green Belt demarcated the space of engagement for homo economicus. It created a blank canvas 'where industry was not' that signposted, as much as it constrained, the possibilities for the expansion of economic growth (Williams, 1980: 80). In bounding the limits of the urban, this circuitous network served to connect as well as divide. Green Belt provided the circulatory system around which a Combined Authority could be enrolled (Swyngedouw, 2006). For Abercrombie in his 1944 Greater London plan, the outer circuit of Green Belt inspired a model of urban regional development designed in concentric rings. In 1945 the Manchester and District Regional Planning Committee conceived of a 200,000-acre Green Belt to connect 14 constituent authorities into a new trans-urban entity (Nicholas, 1945). This circuit, when subsequently extended into the largest Green Belt outside London, mapped out the contours of a northern economic block between Greater Manchester, Liverpool and West Yorkshire. When in 2016 the Greater Manchester Combined Authority published its draft spatial framework, it applied the concept of green topology to establish the spatial linkages between its ten local authorities (GMCA, 2016). This network of green 
infrastructure provided a flexible setting for economic development, presenting 'nature' as quantifiable assets that could contribute to the growth of a city region and channel its expansion (Thomas \& Littlewood, 2010), and it allowed the Combined Authority to announce plans to accommodate the region's expectations of urban growth on Green Belt land. The enrolment of a public around the threat to Green Belt in Greater Manchester is the subject of the next sections. In what follows, I explore the capacity of Green Belt to engage a public in collective belonging both to a production of nature, and, to the urban sub-regional identity of a Combined Authority.

\section{Researching the agency of Green Belt in public engagement}

In late 2016 the Greater Manchester Combined Authority announced plans to reduce the Green Belt around the city region by eight per cent of its total land area in order to accommodate expanded expectations of economic growth. Its draft Spatial Framework set out a vision in which Greater Manchester would compete effectively in global markets and create a Northern counterbalance to the economic powerhouse of London and the South East of England (GMCA, 2016). It allocated sites for new housing, office, industrial and warehousing space and, during the short consultation period on these proposals, nearly 28,000 objections were submitted by people of Greater Manchester protesting against the loss of Green Belt land. Over 40 campaign groups were set up across the conurbation, and in December 2016 a federation of local groups was established in Save Greater Manchester Green Belt which, in early summer 2017, was successful in persuading politicians, especially the new Greater Manchester Mayor, to significantly revise the plans.

The paper builds on research with members of this federation carried out through seven area group discussions with 24 members of campaign committees, and through a qualitative questionnaire which drew narrative responses from 236 participants from 40 groups around the Combined Authority. The seven group discussions were facilitated by the researcher to encourage discussion, disagreement and deliberation, with the moderator limiting questions and prompts only to those required when the two-hour discussions appeared to have reached some conclusion. The intention in adopting this practice was to enable the participants to direct the conversation so that it served as a more informal and discursive 
extension of the organisation's own deliberations (Wilkinson, 1999). The questions for the group discussions and the questionnaire were designed to explore emotional responses to Green Belt, active relationships to it, and awareness of the Combined Authority, and attitudes to Greater Manchester as a spatial identity. Responses were analysed thematically, alongside a desk-top review of campaign materials, consultation responses, websites and social media posts, including videos, images and informal comments. Transcripts were coded according to the agentic role given to Green Belt by respondents. Participants attributed their motivation and sense of efficacy to their connection to, or experiences in Green Belt. They also experienced a degree of identification with each other, as campaigners, and with the city region, that they attributed to their engagement in Green Belt. Excerpts from the research data reproduced in this paper were selected to vividly evidence views that were strongly represented across the sample. Data from the group discussions introduced in the text is indicated by $\mathrm{G}$ followed by the number of the group while material from the questionnaire is marked $\mathrm{R}$ followed by a respondent number.

\section{Caring about each other's backyards}

In co-ordinated actions across the Greater Manchester Combined Authority on 2 January 2017 over five thousand people took part in marches and processions on Green Belt land earmarked in the Spatial Framework for development. These public assemblies brought together walkers, cyclists, horse riders, and bird watchers and affirmed the place of Green Belt as an environmental setting for encounters between human and nonhuman. Like much of England's Green Belt, the land on Greater Manchester's urban fringe is well served with footpaths and bridleways (CPRE \& Natural England, 2010). Walking and riding along footpaths in the company of dogs, horses, and bicycles, the protesters affirmed the materiality of this public mobilisation and the physicality of their engagement with Green Belt.

Green Belt was presented by the campaigners as accessible countryside; a near-at-hand contrast to the economic sphere of daily labour that provided physical release from the world of work. For most, the experience of Green Belt was conducted through the everyday 
routine of walking in the outdoors, often walking with dogs, with accompanying benefits for human wellbeing.

I get my dogs, get my muddy boots on, and go out and within minutes you're out there. I don't mind building houses but why take the land out of Green Belt because it opens it up to a different aspect. It's my piece of mind, that (G6).

The relationship with domestic animals was a prelude to a more extensive engagement in the company of the non-human. In the following narrative, entrance to the natural world of Green Belt is experienced as 'crossing over', as if into a different sphere and, even though the intent is to emphasise accessibility, participants go 'down' to enter Green Belt. This is an experience of bodily immersion.

It is across the road. It is down a lane. I don't have to travel far to immerse myself in it for an hour or so after work (R43).

This practical, embodied engagement with Green Belt, routinely enacted in the company of dogs or horses, shaped an environmental setting that was in opposition to the urban. All the campaigners participating in this research identified the containment function of Green Belt and commented on its benefits in retaining the character of individual settlements and preventing the increasing agglomeration of the Greater Manchester conurbation. The most common description of this containment role was 'breathing space'. This phrase conveyed not only the act of separation but spoke also of the physicality of the experience of Green Belt, its association with exercise and fresh air, with relaxation or 'taking a breather' (R74) and with the mindfulness of breathing associated with meditative states. Participants spoke often of the sense of calmness they experienced walking; they described it in terms of respite; 'it empties your head' (G2); 'I solve all my problems in the Green Belt' (G2).

It gives me a place to de-stress, find head space, and get away from the noise and pollution. It's where I can take my kids, my dog, my bike, my running shoes and remember what is important. I have shown my kids the beauty and startling joy in nature, picnics, mud, sky and space to run and breathe (R39). 
The sensual knowledge gained through walking in the Green Belt fostered an experiential understanding of the 'natural' place of people and positioned humanity as participants in biodiversity. While this regular encounter with nature yielded individual benefits in enhanced wellbeing, the immersion in biodiversity was a collectivising experience; it fostered consideration of the public good, and the good of a public that was not just present and not just human.

It's somewhere I can go and be in nature, it's peaceful, it's somewhere I can relax and feel connected. I enjoy watching wildlife there, walking my dog there, riding horses out through it. I enjoy walking through the landscape with flora and fauna that constantly changes with the seasons, it's meditative. I enjoy the fresh air and the distant muffled hum of traffic. It is also important to me for reasons outside myself, for the greater good. Biodiversity equals a healthy eco system and healthy planet, around a city wild life of all kinds need sanctuary. Our green belt is the last vestiges of countryside we have (R58).

This account is worth quoting in full because it narrates a journey from the materiality of an individual relationship with Green Belt, a sensory experience of physical exertion in the company of animals, to Green Belt as a political symbol, one that sparks the awakening of a public conscience; a 'materially potent object capable of capturing humans in networks of obligation and responsibility' (Hawkins, 2011: 547).

This is a journey too from the domestic sphere, the world of leisure and of domestic animals, to the realm of the political, and to a political public. It portrays the material, the sensuous, the animal, as components of a democratic community and as participants in political struggle (Marres, \& Lezaun, 2011). Green Belt enacts a public that remains immersed in the world of things and of material interests. In contrast to traditions of political thought that require citizens to be 'innocent' of all attachments before they can participate in democratic debate (Irwin, 2006: 315), the Green Belt campaigners emerged into the public sphere with mud, animal hair, and their material interests still attached. Their entrance as campaigners matched this progression from the personal to the political. 
The first thing I said to my wife was if I save one field, I save one field, and that was it. And then I started getting involved with other people and seeing what they're going through and then you think I'll save as many fields as I can (G6).

The mobilisation of the Save the Green Belt campaign was initiated by networking outwards from the particular to the universal, from the material attachments inspired by an individual Green Belt site and onto a commitment to the principles of environmental sustainability and conservation.

When we started our campaign, I kept thinking, where we are living, you know, we've got a great view, I kept thinking no, this is not just about that view, this. This is about what's going to happen in the future for our future generations and if we lose this breathing space between our towns (G3).

Green Belt enacts a public that exists now and as a future collective, and the campaign consciously articulated the 'interests that can be, of a collectivity that may yet become' (Metzger, 2013: 793). Participants became aware of their place in a present and future public, on the basis of their direct encounter with Green Belt as biodiversity. They were 'learning to be affected' (Latour 2004: 206), as bodies in the world, and Green Belt was the setting for their becoming.

For me I think that if one green belt site goes, regardless, it's all green belt sites at risk (G4).

The formation of local protest groups, and their federation across the city region in the Save Greater Manchester Green Belt campaign, expanded an earthy relationship with material interests into commitment to an ecological principle. In a reversal of the planning profession's conventional belief that citizens objecting to development act as self-interested individuals, Green Belt protestors expressed their private interests as wider societal-natural concerns. In response to the quasi-scientific and derogatory nomenclature that has popularised acronyms, such as NIMBY (not in my back yard), to condemn the participation of citizens as selfish and materialistic, they pointed to the materiality of their interests in Green Belt. 
People might call us Nimbys but when you join together, if you're fighting for someone else's backyard you can't be a Nimby can you? You're fighting for a principle. And I think the characteristic of everyone who joins us there, it's on the principle; you care about each other's backyard as well (G5).

Green Belt was invested with the power to convene a public that learned from the immediacy and physicality of earth, plants, dogs and walks that it belonged to a political community (Bennett 2018). This was a production of 'nature' that made the non-human speak of what it means to be human (Latour et al 2018), and how it impacted on the relevance of the Combined Authority as a political forum is explored in the next section.

\section{The whole point was to separate}

Green Belt exerted a power to engage individuals in a collective of humans and the nonhuman and with a sense of obligation and responsibility to the future of this collective. This was a journey into collective becoming that was also an identification with a political territory. Less than two months after the launch of the public consultation on the Greater Manchester Spatial Framework, the local groups protesting the loss of Green Belt had networked into a sub-regional federation. The threat to an individual Green Belt site, and to individual attachments, was translated into a collective concern for Greater Manchester Green Belt, and into the formation of a Greater Manchester public. This regional public was enacted by the network characteristics of Green Belt.

Green Belt was valued by protestors for preserving the cordon of 'nature' that conserved the identity of individual settlements, but it also provided a universalising principle that enabled separate places to communicate and to identify common purpose (Routledge \& Cumbers, 2009). An environmental planning designation that aimed to prevent the amalgamation of urban areas, and retain the distinct character of settlements, had nevertheless the capacity to connect them, to contain space and to thread people into places. It suggested that individual places were already the products of connections and the meeting places of different journeys (Featherstone, 2005). In a discussion with one local Green Belt action group this dual capacity to connect and separate was identified: 
It's a perfect example of successful greenbelt. It does its purpose. The whole point of green belt was to separate areas.

But looking at it now, I can see it actually is a resource, you know, for the wider community. It's not just the people who live here. It's people, you know, who live out. You've got the connection of the cycle path that goes along the canal from Manchester, and I've met people around here you know who cycle from Manchester, you know (G2).

The image of Green Belt as a network of connectivity that links as it separates provided an organisational metaphor for the combination of over 40 local groups in the Save Greater Manchester Green Belt campaign. The federation was established through connections made on the internet social networking site Facebook, and posts to this site were used to convene meetings, advertise events, and communicate information between members. Campaign group members journeyed to the location of other groups in the network to take note of the shared threat to Green Belt sites. The journey across Greater Manchester became a memorable part of the encounter with difference and similarity and mapped the shape of the region. The sights, the feeling - the materiality of travelling and meeting, are remembered by this campaigner:

Maybe that's the first time we met as Save Greater Manchester. I think it was just before Christmas. I can picture going to Manchester and the Christmas lights, so it must have been then. But then we were trying to get together and gel. Load of different people with strong characters there (G7).

In offering a universalising principle of place and nature, Green Belt extended a networking capacity that was not wholly symbolic but materially experienced. It provided a shared physical infrastructure that, in separating settlements, mapped the boundary of a conurbation. It functioned as the contrasting companion to the infrastructure of road and other infrastructure networks that defined the space of possibilities for a city region, as one participant explained.

I remember driving on the $\mathrm{M} 60$ before all this kicked off, and thinking, what a great city this is, you know. I think what a great city we have with everything going on in the centre. But then to have all this green on the outside, you know. And it's quite 
impressive. You drive down the M60 from here for miles and its green both sides. You think, that's really good to be so close to one of the major cities in the UK, and actually to have that for the people who live in it. And I was thinking, that must be design, that must be part of a plan to keep it like that. And actually, no. (Laughter). It was the other way. But why would you? Why would you want to lose that? It doesn't make any sense (G2).

The capacity of Green Belt to inspire a topological imagination can be glimpsed in this excerpt from the campaign discussion. In orienting participants to the non-human, and to a another spatio-temporal rhythm, the Greater Manchester Green Belt opened a crossing point in the boundaries of the local. In its physical enclosure of the space of the urban it emphasised the proximity of other campaign groups, establishing a 'convergence space' of protest in which other threatened Green Belt sites were pulled nearer together and the connecting routes between them were made familiar (Cumbers, Routledge \& Nativel, 2008). This 'placing' effect of Green Belt increased the relevance of Greater Manchester as a political entity, and as a site of democratic engagement. Local campaign groups quickly discovered the limits of negotiation with their ward councillors, who were sometimes ignorant of the proposals in the Spatial Framework, and often keen to redirect responsibility for the plan on to the Combined Authority. The commitment to the consultation process by political leaders was highly uneven across the ten local authorities in the city region, and the election of a Greater Manchester Metro Mayor became the focus of the Save Greater Manchester Green Belt federation (Haughton, 2018). At political hustings organised by the campaign group, the Labour Party mayoral candidate Andy Burnham pledged to roll back on the Green Belt plans and after his election he ordered a radical rewrite of the Spatial Framework.

The Save Greater Manchester Green Belt federation never supplanted the role of the local campaign groups, and was seen, even by its most active organisers, as a tactical alliance that could exert political pressure on the Combined Authority and achieve a wider reach of publicity. Reflecting on this orientation to a trans-urban space of governance the campaigners commented on the changed setting for their collective belonging.

If you'd asked me before I'd have said, we had nothing to do with Manchester. And now actually because of joining that group I now feel part of something, part of it (G6). 
I think it brought in those who didn't really regard themselves as part of Greater Manchester or, you know, you're Lancashire or Cheshire, you know, you don't regard yourself as Greater Manchester, this is a man-made thing. I think there was never a feeling that we were part of it in any place. But we do use it now (G3).

The Greater Manchester Combined Authority was made relevant to the residents hailed in its imagined community by the threat to Green Belt. Campaign groups in each neighbourhood mobilised objections to the Spatial Framework and participated in the Mayoral elections, seeking to influence the strategy of candidates, and the Save Greater Manchester Green Belt federation organised regional conferences to direct the spatial strategies of the Combined Authority towards town centre renewal and more participatory planning.

The first draft of the Greater Manchester Spatial Framework in 2016 presented the loss of Green Belt as an issue of the identity of the city region and its economic expansion. It invited participants to join in a vision of the Combined Authority as a global power, assuming that this collective identity was already shared, and that the political imaginary was relevant to the population. The Spatial Framework energised a public that arose in opposition to its plans and to the loss of Green Belt and was, at least initially, viewed as illegitimate by strategic planners and politicians. The second draft of the Greater Manchester Spatial Framework, just published at the time of writing, aimed to provide a more compelling argument for the relevance of the Combined Authority as a political identity (Haughton 2018). The 2019 Spatial Framework attempted to demonstrate a strategic approach to development that was attuned to the Greater Manchester public enacted by its resistance to the loss of Green Belt; it pledged affordable housing and town centre regeneration and conserved half the threatened Green Belt sites (GMCA, 2019).

Public participation in new spaces of governance such as the English Combined Authorities can be understood as a problem of establishing relations of relevance between the publics entangled in issues, and the sites and practices of policy formation (Marres, 2012). The mobilisation of the Save Greater Manchester Green Belt campaign, with its federated groups, was evidence of the power of objects, things and settings in 'relevancing' the sites of democratic governance (Marres, 2012: 145). The material attachments of the human for the non-human assembled a collective identity of the Combined Authority. Plants, birds, 
soil, dogs and horses were companions in the Green Belt campaign, and served as active mediators connecting people and sites, and enacting Greater Manchester as a space of shared political obligation to a hybrid present-and-future community (Jasanoff, 2010), a 'collective becoming' of people, objects and things (Metzger 2013a: 793). The network characteristics of Green Belt, with their capacity to place and connect, provided the topological imaginary of a community of the affected, a Greater Manchester collective that was emergent, sensuous and much more than human.

\section{Conclusion}

In investigating the problem of relevance in the English Combined Authorities, and the spatial restructuring of governance more generally, this paper has pointed to the capacity of objects, things and their settings - and specifically Green Belt as an assemblage of all three components - in organising public participation. Objects, or hybrid assemblages such as Green Belt, can be understood to possess powers of engagement; that is, they mediate human attachments to the non-human and inspire passionate concern, enough to launch publics into being and spur them into political action. The power to engage that can be exercised by objects has been long recognised in the spatial planning system, and is exemplified in Green Belt, as the territorial organisation of attachments between humans and the non-human. The passions aroused by Green Belt are familiar, and sometimes disparaged, but the capacity to arouse public concern is a political accomplishment and one essential to the collective becoming of political communities.

This paper contributes to the literature on material participation by evidencing the capacity of Green Belts to bestow political identity and a sense of collective belonging on new institutions of spatial governance. The passionate associations and connections inspired and organised by Green Belts enabled publics to participate in and perceive the relevance of the Greater Manchester Combined Authority. In its production of nature, Green Belt facilitated a progression from the domestic to the political, and from the physical exertion of walking and the materiality of muddy boots, to an immersion in environmental principles, and in the obligations owed to a community of things and to future generations. As a physical belt or girdle that contained and provided the container for a sub-regional conurbation, Green Belt 
established the topological infrastructure for the collective identity of the Combined Authority. While its role was to separate, Green Belt initiated a network that brought an urban public into proximity, and democratic processes within reach, giving practical, earthy shape to a territorial imaginary of spatial governance. The public addressed in the spatial reorganisation of governance is entangled in material interests that enlist their concern and orchestrate their participation. The relevance and appeal of the new Combined Authorities of English governance rests, in part, on an appreciation of the attachments between people and things, and the capacity of the non-human to organise civic engagement.

\section{Bibliography}

Amati, M. \& L. Taylor (2010) From green belts to green infrastructure. Planning, Practice \& Research. 25, 2: 143-155

Anderson, B. (1991) Imagined communities: reflections on the origin and spread of nationalism. London. Verso.

Barry, A. (2001) Political machines: governing a technological society. London. The Athlone Press

Bennett, J. (2018) Whose Place is this Anyway? An actor-network theory exploration of a conservation conflict. Space and Culture, 21, 2: 159-169

Bennett, J. (2010) Vibrant Matter: a political ecology of things. London. Duke University Press

Callon, M. (1986) Some elements of a sociology of translation: domestication of the scallops and the fishermen of St. Brieuc Bay. In: Law, J. (ed.) Power, action and belief. London, Routledge: 196-233

Castells, M. (2012) Networks of outrage and hope: social movements in the internet age. Cambridge. Polity Press 
Chilvers, J. \& M. Kearnes (2016) Science, democracy and emergent publics. In: Chilvers, J. \& M. Kearnes (eds.) Remaking participation: science, environment and emergent publics. London. Routledge: 1-28

CPRE [Campaign to Protect Rural England] and Natural England (2010) Green Belts: a greener future. London. CPRE/Natural England

Cumbers, A., P. Routledge, C. Nativel (2008) The entangled geographies of global justice networks. Progress in Human Geography. 32,2: 188-201

Duff, C. (2011) Networks, resources and agencies: on the character and production of enabling spaces. Health \& Place, 17: 149-156

Farias, I. (2010) Introduction: decentring the object of urban studies. In: Farias, I. \& T. Bender (eds.) Urban Assemblages: how actor-network theory changes urban studies. Abingdon, Routledge 1-24

Featherstone, D. (2005) Towards the relational construction of militant particularisms: or why the geographies of past struggles matter for resistance to neoliberal globalisation. Antipode, 37,2: 250-271

Freestone, R. (2002) Greenbelts in city and regional planning. In: Parsons, K.C. \& D. Schuyler (eds.) From garden city to green city: the legacy of Ebenezer Howard. London. John Hopkins University Press: 67-98

Gallent, N., J. Andersonn, M. Bianconi (2006) Planning on the urban edge: the context for planning at the rural-urban fringe. London. Routledge

GMCA (Greater Manchester Combined Authority) (2017) Draft Greater Manchester Spatial Framework. Manchester. GMCA

GMCA (Greater Manchester Combined Authority) (2019) Draft Greater Manchester Spatial Framework. Greater Manchester's Plan for Homes, Jobs and the Environment. Manchester. GMCA

Haughton, G. (2018) Learning from the GMSF process. Town and Country Planning. 87 (1) $18-21$. 
Hinchcliffe, S., M.B. Kearnes, M.Degen, S. Whatmore (2005) Urban wild things: a cosmopolitical experiment. Environment and Planning D: Society and Space, 23: 643-658 House of Commons (2017) Combined Authorities. Briefing Paper Number 06649, 4 July. London. House of Commons Library, UK Parliament

Irwin, A. (2006) The politics of talk: coming to terms with the 'new' scientific governance. Social Studies of Science. 36,2: 299-320

Jasanoff, S. (2010) A new climate for society. Theory, Culture \& Society, 27 (2-3): 233-253 Latour, B. (1988) The Pasteurization of France. Cambs, Mass. Harvard University Press Latour, B. (1991) We have never been modern. Trans. C. Parker. Cambs, Mass. Harvard University Press

Latour, B. (1999) Factures/Fractures: from the concept of network to the concept of attachment. Res: Anthropology and Aesthetics, 36, $20-31$

Latour, B. (2004) Politics of nature. Cambridge, Mass. Harvard University Press Latour, B. (2005a) Reassembling the social: an introduction to actor-network theory. Oxford, OUP

Latour, B. (2005b) From realpolitik to dingpolitik or how to make things public. In: Latour, B., \& P. Weibel (eds.) Making things public: atmospheres of democracy. Cambridge, Mass. MIT Press: $14-43$

Latour, B., D. Milstein, I. Marrero-Guillamon \& I. Rodriguez-Giralt (2018) Down to earth social movements: an interview with Bruno Latour. Social Movement Studies, 17, 3: 353-361 MHCLG [Ministry of Housing, Communities \& Local Government] (2018) National Planning Policy Framework. London. MHCLG

MHLG [Ministry of Housing \& Local Government] (1955) Green Belts. Circular 42/55. London. HMSO MHLG [Ministry of Housing \& Local Government] (1962) The Green Belts. London. HMSO 
McFarland, C. (2009) Translocal assemblages: spaces, power and social movements. Geoforum, 40: 561-567

Marres, N. (2012) Material Participation: technology, the environment and everyday publics. Basingstoke. Palgrave Macmillan

Marres, N. (2005a). No issue, no public: democratic deficits after the displacement of politics. Amsterdam. Ipskamp Printpartners

Marres, N. (2005b) Issues spark a public into being: a key but often forgotten point of the Lippmann-Dewey debate. In: Latour, B. \& P. Weibel (eds.) Making things public: atmospheres of democracy. London, MIT Press

Massey, D. (2005) For Space. London. Sage Publications

Metzger, J. (2013a) Placing the stakes: the enactment of territorial stakeholders in planning processes. Environment and Planning A, 45: 781-796

Metzger, J. (2013b) Raising the regional leviathan: a relational-materialist conceptualisation of regions-in becoming as publics-in-stabilisation. International Journal of Urban and Regional Research. 37 (4): 1368-1395

Mol, A. \& J. Law (1994) Regions, networks and fluids: anaemia and social topology. Social Studies of Science, 24 (4): 641-671

Murdoch, J. (1998) The spaces of actor-network theory. Geoforum, 29, 3: 357-374

Nicholas, R. (1945) The Manchester and District Regional Planning Committee: report on the tentative regional planning proposals. Norwich and London. Jarrold \& Sons Ltd Porter, L. (2010) Unlearning the colonial cultures of planning. Ashgate Publishing Ravenscroft, N. (1998) Rights, citizenship and access to the countryside. Space and Polity, $2: 1,33-48$

Routledge, P. \& A. Cumbers (2009) Global justice networks. Manchester, Manchester University Press

Stengers, I. (2005) The cosmopolitical proposal. In: Latour, B., \& P. Weibel (eds.) Making things public: atmospheres of democracy. Cambridge, Mass. MIT Press: 994-1003 
Swyngedouw,E. (2006) Circulations and metabolisms: (Hybrid) Natures and (Cyborg) cities, Science as Culture, 15:2, 105-121

Thomas, K. \& S. Littlewood (2010) From green belts to green infrastructure? The evolution of a new concept in the emerging soft governance of spatial strategies. Planning, Practice \& Research. 25,2: 203-222

Wilkinson, S. (1999) How Useful are Focus Groups in Feminist Research? In: Barbour, R. \& J. Kitzinger (eds.) Developing Focus Group Research. London, Sage.

Williams, R. (1980) Problems in Materialism and Culture: selected essays. London. Verso Editions and NLB.

Zakhour, S. \& J. Metzger (2018) Placing the action in context: contrasting public-centred and institutional understandings of democratic planning politics. Planning Theory \& Practice, 19 (3): $345-362$ 